\title{
Perceived Quality of Distance Education from the User Perspective
}

\author{
Tolga Dursun, Kader Oskaybas, \& Cansu Gokmen \\ Maltepe University, Turkey
}

\begin{abstract}
The purpose of this study is to measure the quality of distance education services received from educational institutions which are among the leading service enterprises. More specifically, the study aim to find out what the students' expectations are, to what extent the student expectations are met and whether or not the acquired findings vary according to demographical characteristics of students. Moreover, this study is an attempt to assess if there are any differences among similar higher education institutions that implement distance learning programs in terms of the perceived quality of their educational services. It is hoped to help improve the quality of existing higher distance education services by evaluations based on the results of a comparative study. Therefore, through the SERVQUAL methodology, the current study has focused on determining the level of satisfaction regarding expectations and perceptions of students as customers. The data in the study were collected through a survey administered to a total of 463 university students. The examination of partial SERVQUAL scores and relevant analyses indicate that expectations are not met for any of the five dimensions affecting service quality in the universities providing e-MBA education through distance learning.
\end{abstract}

Keywords: Distance education; Service quality; SERVQUAL; Higher education; Service expectations; User perspective

\section{Introduction}

On the one hand, developments and changes as a consequence of globalization have significant effects on people's lives, needs, and desires. On the other hand, they influence both the understanding and form of how these needs are met. Educational service is one of service fields at the most critical point of the service sector. Because people who will work in their professional fields in the future are trained through education. In this respect, improving the quality of service of higher education at universities serves toward the purpose of integrating people to 
the society as individuals providing the highest benefit in the fields that they are trained for.

In the twenty-first century, with the explosion of information, it has been observed that the need for education of all communities/countries has increased. The need for education has brought the development of new educational technologies and new methods of education and training, and these ultimately have developed new methods and techniques and gradually changed the very nature of education. Traditional educational institutions cannot meet the increasing demand for more and further education. The education gap is increasing every day.

This requirement has pushed societies to search for alternatives to the traditional educational systems, and "distance education" has emerged a viable alternative. Probably the most important reasons for this serious change in education are related to the increasing number of students and their growing educational demand, including life-long learning needs of all sectors of the society mostly coming from the business world or and work life.

Gronroos service is defined as an activity or series of activities which are more or less abstract and provide solutions to customer problems that occur during the encounter of customer with physical resources of the goods or systems of the staff serving or providing the service (Goktolga \& Ozkan, 2011, p.66). This definition focuses on the interaction dimension of the service. Concrete elements that impact and contribute to the interaction dimension of the service are involved in the process. Skinner service is also called as abstract works that are created by individuals and machines through people and tools, which provide direct benefit to the customers (Okumus \& Asil, 2007, p.8).

The concept of quality is defined by Deming as "customer judgment about the product or service produced by the business" (Deming, 1998, p.137), and by Crosby (1979) as the "degree of compliance of a product with the requirements." The definition of quality specified in the TSE (Turkish Standards Institute) standards is "the sum of the features of a particular product or service based on the determined or probable needs. Defining the quality of service includes two perspectives as internal and external. According to the internal perspective, the quality of service is defined within the framework of customer perceptions, expectations, attitudes, and satisfaction (Sachdev \& Verma, 2004, p.97). The quality of service is to give an excellent service to meet customer expectations. For another definition for the quality of service, it is defined as meeting customer expectations completely or exceeding those expectations. 
When the quality of service is further analyzed, it can be seen as a comparison between customer expectations and his/her perceptions (Parasuraman, Zeithaml, \& Berry, 1985, p.42). Customer interprets the quality by herself/himself detecting many factors, and compares the services that $s /$ he received and expected.

\section{Quality, Service and Service Quality}

Kotler (2003, p.444) says that "a service is any act or performance that one party can offer to another that is essentially intangible and does not result in ownership of anything. Its production may or may not be tied to a physical product." Today, we live in a service economy in which relationships are much more important than physical products. However, how high the share of technology in a service offered may be, main component is human being. Therefore, service, provided either by machine or human, is a whole of intangible activities oriented to meet demands of people. As for service organizations, they lie across a broad spectrum ranging from education, health and communication to banking, insurance business and tourism (Armstrong \& Kotler, 2000).

The concept of quality, according to Deming (1998, p.137), is the "judgment of consumer on product or service produced by a business firm" and is "conformity level of a product to requirements" for Crosby (1979). Turkish Standards Institute (TSE) defines quality as "whole of the features of a product or a service, based on its capability to meet the given or possible needs". Generally, all the definitions of quality concern product quality, falling behind explaining service quality. Whereas the concept of service quality is defined by Parasuraman, Zeithaml, and Berry (1988 p.45) as the direction and degree of the gap between expectations and perceived performance based on comparison made by customers between their expectations before receiving service and their real service experience.

In terms of expectations and perceptions of customer, service quality can be defined by Parasuraman, Zeithaml, and Berry (1985, p.42), as comparison between those expectations and perceptions. Perceiving many factors, the customer interprets quality in his/her way and compares service rendered with service he/she perceived. What is important here is that customers should perceive high level of service. If a comparison gives a negative difference between expected and perceived qualities, it is obvious that customer interpreted the service quality negatively. If the result is a positive difference, then it may be said that customer made a positive interpretation (Degermen, 2006).

Service quality is described by Sekerkaya (1997, p.14) as "a measure of realization level of service by customer's expectations". Howsoever difficult to define service 
quality, business managements should know these two things: At first, quality is defined by customer not by producer. Second, service quality which has failed to satisfy customers' expectations is condemned not only to lose existing customers but also to fail to gain new customers (Stanton, Etzel, \& Walker, 1997, p.524). Again the point is that quality determinant is the customer and so firms should give weight to demands of their customers.

\section{Measuring Service Quality}

The emergence of several instruments of measurement such as SERVQUAL (Parasuraman, Zeithaml, \& Berry, 1985), SERVPERF (Cronin \& Taylor, 1994) has made contribution to the evolvement in the study of service quality. Although many methods and means have been developed for measuring service quality by this time, the general survey method has been combined with SERVQUAL as an assessment method while conducting the research project designed for measuring service quality of education service rendered with e-MBA programs in distance education.

\section{Conceptual Model of Service Quality-Gap Analysis}

This model developed by Parasuraman, Zeithaml, and Berry $(1985$, p.48) prefer "perceived service quality" instead of service quality. Perceived service is a result of comparison between customer's expectations before receiving service (i.e. expected service) and actual service experience of that customer. Expectations include demands and desires of customers related to given service. Relationships between expected and perceived services are as follows:

(a) If expected service is > perceived service, then perceived quality is far from satisfactory and implies an unacceptable quality level.

(b) If expected service is = perceived service, then perceived quality will be satisfactory.

(c) If expected service is < perceived service, then perceived quality will be quite over satisfactory level and reach the ideal quality level.

This model includes approaches and implementations of the service firms along with gaps between expected and perceived service and source of these gaps. In this context, five types of gap are shown in Figure 1 (Parasuraman, Zeithaml \& Berry, 1994, p.4). 


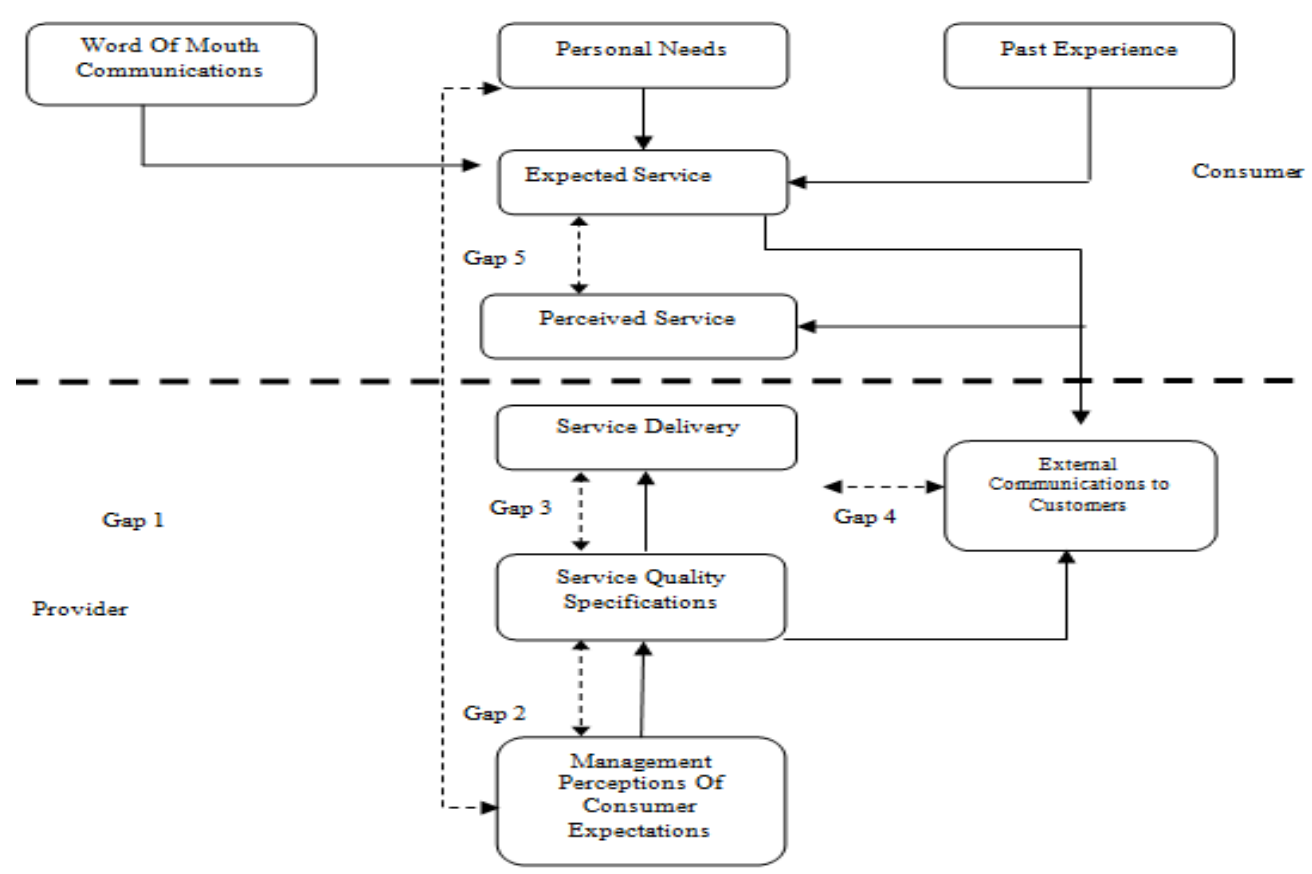

Figure 1. Conceptual Model of Service Quality

Zeithaml, Berry, and Parasuraman (1990) revealed that 10 criteria used by consumers in evaluating service quality. These are: reliability, responsiveness, competence, access, courtesy, communication, credibility, security, empathy, and tangibles. Having assessed surveys with factor analysis and reduced 10 dimensions determining service quality for 5 dimensions. Those five dimensions determining service quality are tangibles, reliability, responsiveness, assurance, and empathy (Eleren, Bektas, \& Gormus, 2007).

\section{Purpose of the Study}

The purpose of this research is to find out students' opinions and evaluations regarding the quality of distance education services they receive from educational institutions as one of the leading areas in the service sector. Toward this purpose, it will be tried to detect whether or not there are differences in the quality of distance education service provided by similar higher education institutions that implement a variety of distance education programs in Turkey. It is aimed that ideas emerging from the evaluation of obtained results will contribute to improving the quality of higher education services. 


\section{Methods}

\section{Instrumentation}

While several methods and means have been developed to measure the quality until today, this research project was designed to measure the quality of service of e-MBA education provided through various distance education programs. Survey is applied as a method of collecting data, and SERVQUAL is implemented as a method of evaluation.

SERVQUAL model, developed by Parasuraman, Zeithaml, and Berry (1994), is a model accepted and applied extensively to measure the quality of service all around the world. In this model, "perceived service quality" statement is used instead of the quality of service. Perceived service is the result of a comparison between customer expectations prior to receiving the service (expected service) and the actual experience of service $s /$ he benefited, and it is evaluated as the degree and direction of the difference between customer expectations and the perceived performance. Expectations refer to customer wishes and desires for the service.

The relations between the expected service and perceived service are as follows: When expected service is greater than perceived service, the perceived quality is far from satisfactory, and an unaccepted level of quality will come into being. When expected service is equal to perceived service, the perceived quality will be satisfactory. When expected service is smaller than perceived service, perceived quality will be higher than the satisfactory; and the ideal level of quality will come into being (Parasuraman, Zeithaml, \& Berry, 1985, pp.48-49).

This model generally includes the differences between approaches and practices of businesses providing the service and expectations of customers benefiting the service, and sources of these differences.

There are a total of 10 dimensions that determine the quality of service. Then, Parasaruman Zeithaml, and Berry (1991), evaluating surveys that they have applied through factor analysis and reducing the ten dimensions that determine the quality of service to five dimensions, have developed a questionnaire which is a service of quality measurement tool as they have called it as Servqual. These five dimensions in the survey consist of physical features, reliability, readiness, trust (ability, courtesy, credibility and security), and empathy (accessibility, communication, and customer understanding). 
The questionnaire used in the present study consists of a prior knowledge word addressed to respondents, 22 Likert-type questions measuring expectations and perceptions, and questions reflecting the demographic characteristics of the participants. In the first section of the study, 22 variables representing all 5 dimensions (reliability, readiness, trust, empathy, physical features), which help to understand the general expectations of students for education that they receive, are adapted according to features of distance education.

Perceptions constitute the second part of the model. In this section, all of 22 variables that measure the evaluations of students about the universities providing distance education are compared. All in all, if the received service meets the expectations or is above expectations, it is concluded that the service has good quality. Otherwise, if the received service is below expectations come into being, and then there is a feeling of dissatisfaction. For this reason, SERVQUAL model is also called as gap analysis model.

\section{Population and Sample}

In Turkey, distance education at universities includes associate degree programs, undergraduate programs, graduate programs, and certification programs. In recent years, the number of distance education students has increased significantly. Therefore, in order to use this potential, many universities have started to focus on distance education programs. Today, there are 156 universities (54 of which are private universities) in Turkey.

The number of universities providing distance education with an e-MBA program in Turkey is 21. However, this number also includes universities which will start programs in the near future and will accept students then These universities are: Anadolu University, Ankara University, Ataturk University, Bahcesehir University, Beykent University, Cukurova University, Ege University, Fatih University, Gazi University, Ankara University, Isik University, Istanbul Aydin University, Istanbul Bilgi University, Istanbul University, Karadeniz Technical University, Maltepe University, Mersin University, Ondokuz Mayıs University, Sakarya University, Suleyman Demirel University, and Zirve University.

The research population consists of students studying in the universities with an eMBA program. A total of 21 universities with an e-MBA Education Program have been identified; however, the questionnaire of this study has been applied to five universities with e-MBA program through distance education by taking into account of the difficulty and time limit to reach all of them. The sample of the study then consists of all students of 5 universities selected from universities providing e- 
MBA education through random sampling. The names of these five universities included in the study are not given in accordance with their privacy requirements, and referred to as 1-2-3-4-5. Simple random sampling is a method in which sampling units are selected by giving an equal probability of being withdrawn for each sampling selection (Gegez, 2005, p.189). All of the students attending distance education e-MBA programs in these five universities were included in the sampling. All students within the scope of the research were informed about the study, and were requested to participate in the study online. Each student was given the right to participate in the Internet survey with a user name and password assigned to her/him. A total of 463 students entered the system during the period of data collection in this study.

\section{Data Analysis}

Data obtained in this survey were computerized in Microsoft Excel and SPSS 18.0 programs. Specific calculations and statistical analysis used in SERVQUAL model were made by SPSS system. A survey is prepared having 22 questions related with five dimensions - reliability, responsiveness, credibility, empathy and tangibles- on SERVQUAL scale. According to the model, consumers have expectations about those five variables before receiving service and then compare these expectations with the service given. If the service they receive meets their expectations, it is concluded that the service is of quality. In other words, service quality is equal to discrepancy/gap between expected and perceived service.

In this study, 22 statements were put into each survey form with a view to determine expectations and perceptions in accordance with five dimensions of the standard SERVQUAL scale as developed by Parasuraman, Zeithaml, and Berry. Students were asked to state to what extent they agree with each of the 22 statements at a scale of 1 to 5 at first for an ideal university having e-MBA program, and next their current universities. Degrees of agreement were designed as 1Strongly disagree, 2-Disagree, 3-Neutral, 4-Agree, 5-Strongly Agree. Next comes the scoring part for each dimension assessment on the scale of 100 to calculate importance weights of each quality dimension.

The other part of the data gathering instrument includes questions directed to obtain students' demographic information, their satisfaction level with the e-MBA programs that they have chosen, whether or not they faced with any problem during education and whether or not they find the solutions offered adequate, how they think about recommending the program they attended. The 22 questions prepared for expectation and perception levels on the scale are distributed as follows and the statements composing dimensions are shown in Table 1. 
Table 1. Statements Composing Service Quality Dimensions

\begin{tabular}{|c|c|}
\hline Statement & PHYSICAL/TANGIBLE FEATURE \\
\hline 1 & Distance Education Portal should always be accessible/usable \\
\hline 2 & $\begin{array}{l}\text { Sufficient number of most recent sources (Book, Journal, Article, Electronic Databases, } \\
\text { etc...) in library should be accessible. }\end{array}$ \\
\hline 3 & Web page should have striking, clear, understandable and good view. \\
\hline \multirow[t]{2}{*}{4} & Safe environment should be ensured in the Distance Education Portal. \\
\hline & RELIABILITY \\
\hline 5 & Courses, in large part, should be practice-oriented (e.g. case study) \\
\hline 6 & Students should be prompted to group works in practice oriented parts of courses \\
\hline 7 & Students should be allowed to contend for prize such as degree, incentive etc... \\
\hline 8 & Students should be in interaction with faculty members and other students \\
\hline \multirow[t]{2}{*}{9} & Program should offer elective courses to meet personal needs for career \\
\hline & INTEREST-RESPONSIVENESS OF FACULTY MEMBERS AND ADMINISTRATIVE STAFF \\
\hline 10 & $\begin{array}{l}\text { Faculty members should help students in every matter for which they need counselling } \\
\text { immediately. }\end{array}$ \\
\hline 11 & Faculty members should be available at extracurricular times \\
\hline 12 & $\begin{array}{l}\text { Administrative staff should deal with each student one by one (registration procedures, } \\
\text { course selection, etc...) }\end{array}$ \\
\hline \multirow[t]{2}{*}{13} & Library staff should meet demands and needs of students immediately \\
\hline & CREDIBILITY \\
\hline 14 & Lectures should be given by the faculty members who are expert in their fields \\
\hline 15 & Course contents should be prepared in accordance with course schedule \\
\hline 16 & Course content should be prepared conspicuously and given by faculty members \\
\hline 17 & Faculty members should be fair in grading \\
\hline 18 & Faculty members should be experienced \\
\hline \multirow[t]{2}{*}{19} & Coursed should be largely given by faculty members with Prof. title \\
\hline & EMPATHY \\
\hline 20 & Faculty members should help students and give advices on their career planning \\
\hline 21 & Advisers should help students complete the program smoothly \\
\hline 22 & $\begin{array}{l}\text { Students should be provided with advisory service about employment opportunities } \\
\text { offered by the diploma they are to get by this program }\end{array}$ \\
\hline
\end{tabular}

Service quality determinant is the gap/discrepancy between performance of and expectations for a given service as to its receiver. For the analysis, gap score calculation is made by subtracting the expectation score from the perception score for each item that e-MBA students give. This operation is open to two types of SERVQUAL scoring: Unweighted SERVQUAL Score and the Weighted SERVQUAL 
Score. First step is calculated without taking into account the importance weight rated for each quality dimension by students while the later takes accounts of the importance weight given by students. Next step is the calculation of average SERVQUAL Score involving service quality dimensions.

\section{Findings}

SERVQUAL scale applied here was analyzed in terms of its reliability and alpha coefficients established in a view to determine its internal consistency. In these analyses, descriptive statistics including frequency tables, cross tabulation tables, and averages were used as well as t-test and ANOVA in comparing service quality scores by participants' demographic aspects and universities. ANOVA analyses conducted in comparing service quality levels by demographic features and universities are accompanied by Levene test for homogeneity between groups and Tukey post hoc test for determining between which groups discrepancies occur. However, when Levene test results in inhomogeneity between groups Welch test is put into use, not ANOVA. It is shown on statistics tables which analysis was used. Survey findings were assessed by distinctive calculation method of SERVQUAL system and analyzed by some statistical techniques.

\section{Findings of Reliability Analysis}

Gegez (2010, p.184) explained that reliability indicates whether or not the same results would be obtained when a research is repeated and whether respondents would give same answers in case of no change of their state. For reliability analysis in this study Cronbach's alpha model was used. Cronbach's alpha model is the one used for measuring internal consistency, in the words of George and Mallery (2001, p. 209), it is an indicator of to what extent all the items in a scale can successfully measure any dimension.

Table 2. Reliability Coefficients

\begin{tabular}{lcc}
\hline & Expectation & Perception \\
\hline Total scale & \multicolumn{3}{c}{ Cronbach $\alpha$} \\
Tangibles & 0,947 & 0,959 \\
Reliability & 0,887 & 0,812 \\
Responsiveness & 0,791 & 0,873 \\
Credibility & 0,841 & 0,886 \\
Empathy & 0,857 & 0,873 \\
\hline
\end{tabular}


Reliability analysis comes to the front to gauge inter-closeness degree of questions when calculation is made by summating the values of answers to certain numbers of questions. This is also called internal consistency. The most preferred method for reliability analysis is Cronbach Alpha model for scales. This model results in the coefficient alpha. Coefficient is obtained by comparing overall variations of each item to general variation in a scale. Alpha is a standard change mean and varies between 0 and 1 . In social research, alpha value of 0,70 is accepted as adequate for reliability (Nakip,2006, p.146). For in this study reliability values of scales and subdimensions are above acceptable levels, t-tests, variation and SERVQUAL analyses were preceded for testing research hypotheses.

\section{Demographic Features}

Approximately $34 \%$ of total participants were female and $66 \%$ were male, while $51 \%$ participants were married and $41 \%$ single. Students from the $21-30$ age group made $61 \%$ and then the age group between $31-40$ followed with $34 \%$. These two age groups (between 21-40) make up 95\% of the entire participation.

Distribution of the professional sectors that e-MBA service quality measurement study participants work is like this: $14 \%$ is in Banking , $8 \%$ in Health, $8 \%$ in Service, 7\% in Informatics, 7\% in Education, 6\% in Construction; of them 28\% serves as engineer, $16 \%$ as manager, $13 \%$ as banker, $6 \%$ as accountant.

Almost all of the participating e-MBA students (97\%) resides in Turkey. In this distribution, striking point is that participation from Afghanistan with $1 \%$ was the highest one among the participation percentages from abroad. When participation by city is examined, it is seen that the most participation was from Istanbul with $51 \%$, and then comes Bursa with 7\%, Ankara with 6\%, Kocaeli with 5\%, Izmir with $4 \%$, Sakarya with $4 \%$, and Balikesir with $2 \%$.

\section{SERVQUAL Scores Comparisons by Demographic Features}

In order to determine whether or not the expectations of e-MBA students were met in terms of their demographic features, $t$-tests were used for comparison by gender and marital status and variance analyses for comparison by age and income status. 
Table 3. Comparison Test for Service Quality Dimensions by Gender

\begin{tabular}{|c|c|c|c|c|c|c|c|}
\hline & Gender & $\mathbf{N}$ & Mean & $\begin{array}{c}\text { Std. } \\
\text { Deviation }\end{array}$ & $\begin{array}{l}\text { Std. Error } \\
\text { Mean }\end{array}$ & $\mathbf{t}$ & p (sig.) \\
\hline \multirow{2}{*}{ Tangibles } & Female & 158 &,- 172848 & 2554850 & 0203253 & \multirow{2}{*}{$-2,298$} & \multirow{2}{*}{, $022^{*}$} \\
\hline & Male & 305 &,- 121369 & 1644927, & ,0094188 & & \\
\hline \multirow{2}{*}{ Reliability } & Female & 158 &,- 178658 & 2489990, & 0198093, & \multirow{2}{*}{,- 378} & \multirow{2}{*}{ 706 } \\
\hline & Male & 305 &,- 168774 & 2755989, & 0157807 & & \\
\hline \multirow{2}{*}{ Responsiveness } & Female & 158 &,- 186092 & 2197352 & 0174812 & \multirow{2}{*}{,- 611} & \multirow{2}{*}{,542 } \\
\hline & Male & 305 &,- 171451 & 2563722 & 0146798 & & \\
\hline \multirow{2}{*}{ Credibility } & Female & 158 & -167954 & 2550665 & 0202920 & \multirow{2}{*}{$-2,108$} & \multirow{2}{*}{,036 } \\
\hline & Male & 305 & -119978,-, & 2193538 & ,0125602 & & \\
\hline \multirow{2}{*}{ Empathy } & Female & 158 & -,174072 & 1881578 & 0149690 & \multirow{2}{*}{$-1,654$} & \multirow{2}{*}{,099 } \\
\hline & Male & 305 & -142295 & 1999835, & 0114510 & & \\
\hline SERVQUAL & Female & 158 & -,175925 & 1658452 & 0131939 & \multirow{2}{*}{$-1,928$} & \multirow{2}{*}{,055 } \\
\hline SCORE & Male & 305 &,- 144773 & ,1643642 & 0094115 & & \\
\hline
\end{tabular}

Overall SERVQUAL scores do not differ by gender for e-MBA students. However, service quality score differs at sub-dimension of tangibles. Satisfaction level of female students from tangibles is less than male students'. In other words, males are more satisfied with their universities in terms of tangibles in comparison with females.

Table 4. Comparison Test for Service Quality Dimensions by Marital Status

\begin{tabular}{|c|c|c|c|c|c|c|c|}
\hline & $\begin{array}{c}\text { Marital } \\
\text { Status }\end{array}$ & $\mathbf{N}$ & Mean & $\begin{array}{c}\text { Std. } \\
\text { Deviation }\end{array}$ & $\begin{array}{c}\text { Std. Error } \\
\text { Mean }\end{array}$ & $\mathbf{t}$ & p (sig.) \\
\hline \multirow{3}{*}{ Tangibles } & Married & 234 &,- 136325 & 1786907 & ,0116814 & \multirow{3}{*}{ 282 } & \multirow{2}{*}{0,778} \\
\hline & Single & 229 &,- 141605 & 2226850 & 0147154 & & \\
\hline & Married & 234 &,- 188333 & 2920399 & 0190912 & & 0,187 \\
\hline Reliability & Single & 229 & -155607 & 2372965 & 0156810 & $-1,322$ & \\
\hline \multirow{2}{*}{ Responsiveness } & Married & 234 &,- 164306 & ,2262274 & 0147889 & \multirow{2}{*}{1,081} & \multirow{2}{*}{0,280} \\
\hline & Single & 229 &,- 188854 & 2614847 & 0172794 & & \\
\hline \multirow{2}{*}{ Credibility } & Married & 234 &,- 136467 & 2345957 & ,0153360 & \multirow{2}{*}{,- 011} & \multirow{2}{*}{0,991} \\
\hline & Single & 229 &,- 136230 & 2318680 & 0153223 & & \\
\hline \multirow{2}{*}{ Empathy } & Married & 234 &,- 142863 & 1892568 & 0123721 & \multirow{2}{*}{1,138} & \multirow{2}{*}{0,256} \\
\hline & Single & 229 &,- 163639 & ,2033258 & 0134361 & & \\
\hline SERVQUAL & Married & 234 & -,153659 & 1635900 & 0106942 & \multirow{2}{*}{,229 } & \multirow{2}{*}{0,819} \\
\hline SCORE & Single & 229 & -157187 & 1674767 & 0110672 & & \\
\hline
\end{tabular}


Overall and sub-dimensional perceptions of service quality about universities having e-MBA programs differ by marital status of students. As for service quality scores comparison by age variance analyses were used.

Table 5. Payoff Table of Homogeneity Tests for Age Groups Variations

\begin{tabular}{lcccc}
\hline & Levene Statistic & df1 & df2 & Sig. \\
\hline Tangibles &, 379 & 2 & 457 &, 685 \\
Reliability & 1,072 & 2 & 457 &, 343 \\
Responsiveness &, 126 & 2 & 457 &, 882 \\
Credibility & 2,581 & 2 & 457 &, 077 \\
Empathy &, 536 & 2 & 457 &, 586 \\
Servqual &, 573 & 2 & 457 &, 564 \\
\hline
\end{tabular}

According to the variance analysis hypotheses variances of groups to compare should be equal (Homogeneity). Homogeneity of age groups SERVQUAL scores variances were subjected to Levene tests. By means of one-way analysis of variance analysis it was found that total SERVQUAL scores and service quality score variances between age groups for each sub-dimension are homogeneous. As a result of variance analyses, service quality perception from universities with e-MBA learning programs differs by age groups of students attending those universities. ANOVAs were also used in comparing service quality scores by income groups.

Table 6. Comparison Tests for Service Quality Scores by Age Groups

\begin{tabular}{|c|c|c|c|c|c|c|}
\hline & & $\begin{array}{c}\text { Sum of } \\
\text { Squares }\end{array}$ & df & $\begin{array}{c}\text { Mean } \\
\text { Square }\end{array}$ & $\mathbf{F}$ & Sig. \\
\hline \multirow{3}{*}{ Tangibles } & $\begin{array}{l}\text { Between } \\
\text { Groups }\end{array}$ & ,071 & 5 & ,014 & ,350 & ,882 \\
\hline & $\begin{array}{l}\text { Within } \\
\text { Groups }\end{array}$ & 18,678 & 457 & ,041 & & \\
\hline & Total & 18,749 & 462 & & & \\
\hline \multirow{3}{*}{ Reliability } & $\begin{array}{l}\text { Between } \\
\text { Groups }\end{array}$ & 190 & 5 & ,038 & ,533 & ,751 \\
\hline & $\begin{array}{l}\text { Within } \\
\text { Groups }\end{array}$ & 32,644 & 457 & ,071 & & \\
\hline & Total & 32,834 & 462 & & & \\
\hline \multirow{3}{*}{ Responsive } & $\begin{array}{l}\text { Between } \\
\text { Groups }\end{array}$ & ,090 & 5 & ,018 & 301 & ,912 \\
\hline & $\begin{array}{l}\text { Within } \\
\text { Groups }\end{array}$ & 27,493 & 457 & ,060 & & \\
\hline & Total & 27,584 & 462 & & & \\
\hline
\end{tabular}




\begin{tabular}{|c|c|c|c|c|c|c|}
\hline \multirow{3}{*}{ Credibility } & $\begin{array}{l}\text { Between } \\
\text { Groups }\end{array}$ & 199 & 5 & 040 & 731 & ,601 \\
\hline & $\begin{array}{l}\text { Within } \\
\text { Groups }\end{array}$ & 24,882 & 457 & ,054 & & \\
\hline & Total & 25,081 & 462 & & & \\
\hline \multirow{3}{*}{ Empathy } & $\begin{array}{l}\text { Between } \\
\text { Groups }\end{array}$ & ,082 & 5 & 016 & ,422 & ,833 \\
\hline & $\begin{array}{l}\text { Within } \\
\text { Groups }\end{array}$ & 17,739 & 457 & ,039 & & \\
\hline & Total & 17,821 & 462 & & & \\
\hline \multirow{3}{*}{ Servqual } & $\begin{array}{l}\text { Between } \\
\text { Groups }\end{array}$ & ,066 & 5 & ,013 & 477 & ,793 \\
\hline & $\begin{array}{l}\text { Within } \\
\text { Groups }\end{array}$ & 12,566 & 457 & ,027 & & \\
\hline & Total & 12,632 & 462 & & & \\
\hline
\end{tabular}

Table 7. Payoff Table of Homogeneity Tests for Income Groups Variations

\begin{tabular}{lcccc}
\hline & Levene Statistic & df 1 & df2 & Sig. \\
\hline Tangibles & 6,785 & 5 & 457 &, $000^{*}$ \\
Reliability & 1,305 & 5 & 457 &, $261^{* *}$ \\
Responsiveness & 1,332 & 5 & 457 &, $249^{* *}$ \\
Credibility & 1,079 & 5 & 457 &, $371^{* *}$ \\
Empathy & 1,063 & 5 & 457 &, $380^{* *}$ \\
Servqual & 1,307 & 5 & 457 &, $260^{* *}$ \\
\hline
\end{tabular}

*Welch test to be made

** One-way-ANOVA to be made

According to the variance analysis hypotheses, group variances to compare should be equal to each other. Levene tests were conducted for testing homogeneity of SERVQUAL score variances by income groups.

Table 8. Comparing Service Quality Scores between Income Groups by Welch Test

\begin{tabular}{|c|c|c|c|c|}
\hline Welch Test & Statistic $^{\text {a }}$ & df1 & df2 & Sig. \\
\hline Tangibles & 1,339 & 5 & 141,289 &, 251 \\
\hline
\end{tabular}

Having used one-way analyses of variance, test results show that service quality score variances between age groups are homogeneous for sub-dimensions, except for total SERVQUAL scores and tangibles. Welch test was used in analysis of variance for sub- dimension of tangibles because homogeneity hypothesis was not corresponded there. 
Table 9. Comparison Tests for Service Quality Scores by Income Groups (One-way Analysis of Variance)

\begin{tabular}{|c|c|c|c|c|c|c|}
\hline & & $\begin{array}{l}\text { Sum of } \\
\text { Squares }\end{array}$ & df & Mean Square & $\mathbf{F}$ & Sig. \\
\hline \multirow{3}{*}{ Reliability } & $\begin{array}{l}\text { Between } \\
\text { Groups }\end{array}$ & ,557 & 5 & 111 & 1,578 & 165 \\
\hline & Within Groups & 32,277 & 457 & 071 & & \\
\hline & Total & 32,834 & 462 & & & \\
\hline \multirow{3}{*}{ Responsiveness } & $\begin{array}{l}\text { Between } \\
\text { Groups }\end{array}$ & 233 & 5 & , 047 & 779 & ,566 \\
\hline & Within Groups & 27,351 & 457 & ,060 & & \\
\hline & Total & 27,584 & 462 & & & \\
\hline \multirow{3}{*}{ Credibility } & $\begin{array}{l}\text { Between } \\
\text { Groups }\end{array}$ & ,371 & 5 & , 074 & 1,372 & 233 \\
\hline & Within Groups & 24,710 & 457 & ,054 & & \\
\hline & Total & 25,081 & 462 & & & \\
\hline \multirow{3}{*}{ Empathy } & $\begin{array}{l}\text { Between } \\
\text { Groups }\end{array}$ & 151 & 5 & ,030 & ,779 & ,566 \\
\hline & Within Groups & 17,671 & 457 & ,039 & & \\
\hline & Total & 17,821 & 462 & & & \\
\hline \multirow{3}{*}{ Servqual } & $\begin{array}{l}\text { Between } \\
\text { Groups }\end{array}$ & 169 & 5 & ,034 & 1,242 & 288 \\
\hline & Within Groups & 12,463 & 457 & ,027 & & \\
\hline & Total & 12,632 & 462 & & & \\
\hline
\end{tabular}

As a result of analyses of variance it was understood that service quality perception from the universities having e-MBA learning programs do not differ by income status of students.

\section{General SERVQUAL Scores and Its Assessment}

Values obtained as a result of calculations made for realizing SERVQUAL analysis are shown in Table 10. Without taking into account colleges at which students have education, it is observed that service quality score (SERVQUAL score $=0,80456$ ) of institutions rendering e-MBA service is subtractive.

This state indicates that students are not satisfied with service quality of colleges from which they receive e-MBA education. Moreover, it is a clear indication that SERVQUAL scores estimated for service quality dimensions, -tangibles, reliability, responsiveness, credibility and empathy- are also subtractive and expectations for none of them were met. SERVQUAL scores calculated in the table above are the 
values estimated without considering importance weight given by students to service quality dimensions. Service quality SERVQUAL score including importance weights given by students to dimensions is calculated as follows:

SERVQUAL SCORE $=$ (Reliability*importance of reliability + Empathy*importance of empathy +credibility*importance of credibility + tangibles*importance of tangibles + responsiveness*importance of responsiveness) / Number of dimension.

Table 10. Expectation and Perception Averages of All Participants and ExpectationPerception Gap Scores

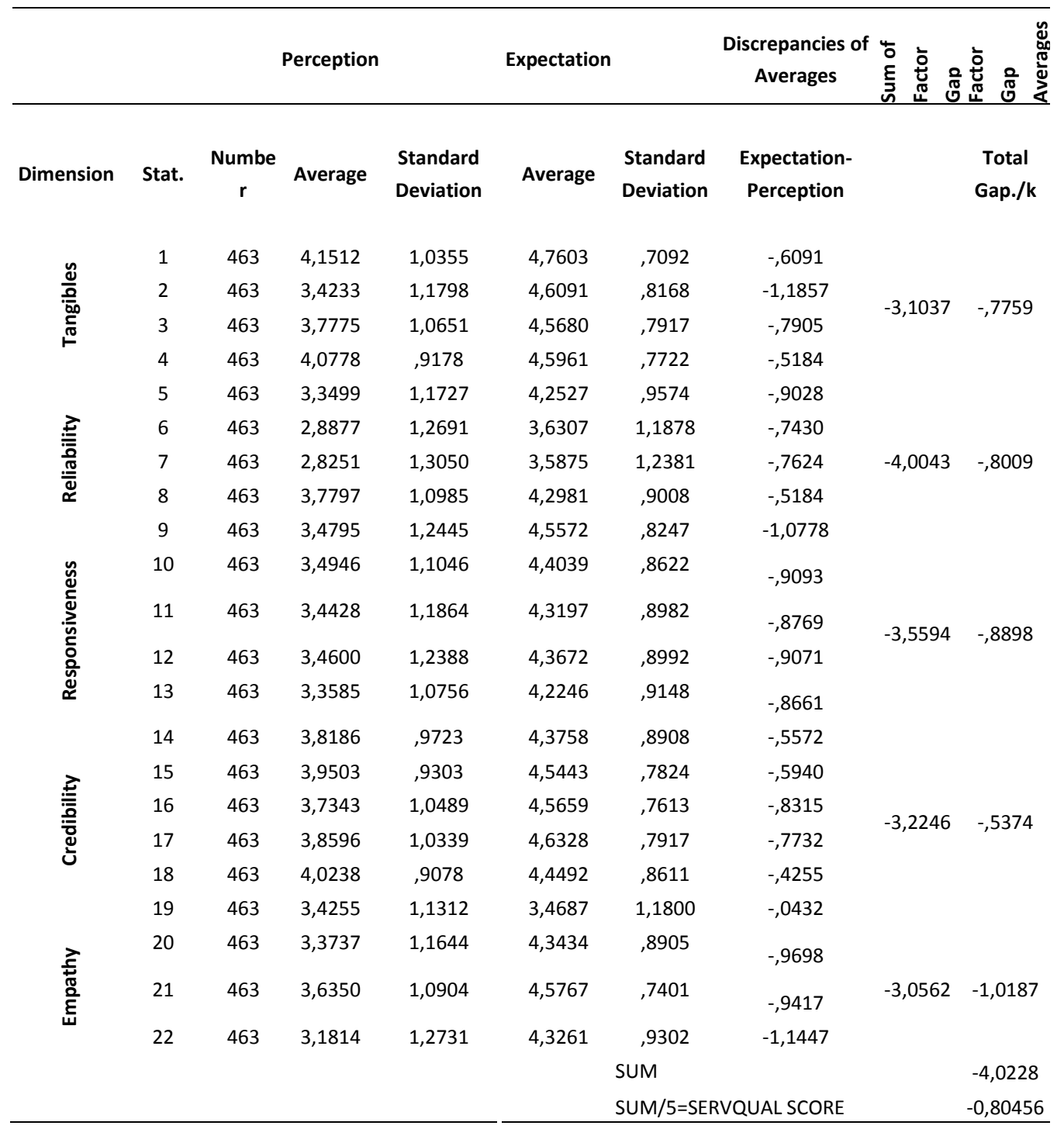

\footnotetext{
* k: Number of statements composing dimension
} 
In this calculation, importance weight is expressed as percentage of importance that student gives to a dimension.

Table 11. Weighted SERVQUAL Scores Table

\begin{tabular}{lccccc}
\hline & N & $\begin{array}{c}\text { Weightless Average } \\
\text { Gaps }\end{array}$ & $\begin{array}{c}\text { Weighted Average } \\
\text { Gaps }\end{array}$ & t & p (Sig.) \\
\hline Tangibles & 463 &,- 7759 &,- 138936 & $-14,840$ &, 000 \\
Reliability & 463 &,- 8009 &,- 172147 & $-13,895$ &, 000 \\
Responsiveness & 463 &,- 8898 &,- 176447 & $-15,538$ &, 000 \\
Credibility & 463 &,- 5374 &,- 136350 & $-12,592$ &, 000 \\
Empathy & 463 & $-1,0187$ &,- 153139 & $-16,777$ &, 000 \\
TOTAL GAPS & & $-4,0228$ & $-0,77702$ & & \\
SERVQUAL SCORE & $-0,80456$ & $-0,1554$ & & \\
\hline
\end{tabular}

Before assessing dimension SERVQUAL scores it was examined that whether or not the discrepancy between perceived and desired service for each dimension is significant; that is, whether or not the discrepancies are statistically valid. For this examination hypothesis " $\mathrm{HO}$ : Gaps equal to " 0 " was tested through the instrument of single sample t-test. As a result of t-tests, it was found that the gaps for all dimensions were significant at level of $p($ sig. $)=0,000$; that is discrepancies were non zero. It was found that service quality scores estimated with no regard to importance weights are $=-0,80456$, while Servqual scores including importance weights are $==-0,1554$. Here the striking point is that results of both estimations are subtractive, meaning that expected service was not met. Next assessments were realized on the basis of weighted SERVQUAL scores.

Absolute value of SERVQUAL score approximation to zero implies an increased service quality. When partial SERVQUAL scores are examined, although service expectations were not met for five dimensions effecting service quality in the universities rendering e-MBA education, the most dissatisfied dimension was responsiveness, followed in order by reliability, empathy, tangibles, and credibility.

\section{Conclusion and Suggestions}

Information technologies, which have lead all organizations to re-arrange their organizational structures and affairs, have become one of the indispensable tools in the educational sector in the course of time. Computer and communications technologies, which were used as support tools in education services in 90's, today appears to be as media through which all of the elements of the education service are provided. One of these technologies is the internet-based distance learning 
model. Internet-based distance learning model is applied in order to fulfil two basic objectives. The first of these is to provide support services to traditional education programs, and the second is to provide educational programs entirely over the network. In this context, the Internet-based distance learning is considered to be one of the most effective and appropriate means to meet education requirements in the current period.

Through distance education systems, students/learners are offered associate, baccalaureate, master's, doctoral degrees as well as various certifications with an education for an academic degree at universities in various countries without going to those countries. The method, which is most frequently encountered in the literature on the measurement of the quality of service, and the most reliable in terms of structure and internal consistency, is Servqual method emerging as a marketing research tool. Owing to Servqual method, which dimension of the quality of service is affected and to which extent the overall quality of service is changed by innovation and developments in the structure of the services offered by businesses can be measured. This can guide such vital and high cost decisions to be made as to which extent the innovation and development can or cannot be applied.

When low quality is determined as the result of the measurement, how much of this is from which dimension must be examined and improvement should be started from the proposition with the lowest quality. In order to improve the issues addressed in the propositions, service delivery must be approached customeroriented, and necessary arrangements should be made. Thus, quality of the service of the perceived service will be increased by raising the scores awarded to perception propositions.

The quality of service of distance education implemented in the education sector was examined in five dimensions as physical features, reliability, readiness, trust and empathy. Without taking universities providing education into consideration, for five dimensions determining the quality of service and the overall quality of service dimension, differences between expectations of students who received education and perceived service quality were analyzed. The differences of scores given by students for the expected service and the expected service were statistically found significant for each dimension.

When partial SERVQUAL scores of dimensions are examined, expected service are not met for students in all of the five dimensions affecting the quality of service at universities with e-MBA education, and the dimension with the most dissatisfaction is readiness and it is respectively followed by reliability, empathy, concrete features and trust. It can be said that the perceptions of the students are below their 
expectations. According to the survey, averages of all the expectations are higher than perceptions. It is found that expectations of participants in this study are not met and there is clear dissatisfaction. It stands out that this difference is prominent particularly in variables of readiness dimension. According to these results, it can be easily said that overall perceptions remained below overall expectations, and a there is a general dissatisfaction.

Whether there was a statistically significant relationship between demographic characteristics of the students and the quality of service that they perceived was investigated. As demographic factors are concerned; age, marital status, income level and gender were examined. As a result of the test, no statistically significant relationship between perceived service of quality and income level, marital status and age was found.

Total SERVQUAL scores of the quality of service of e-MBA students do not differ from each other according to the gender. In the "physical features" dimension, a difference in the perception of the quality of service has been identified by gender, female students have less satisfied than male students.

While there is no significant difference in the dimensions of the quality of service for universities providing e-MBA education according to marital status, age, and income level of the students; differences in dimension of physical features according to the gender have been identified. Satisfaction of women is less than men's in the dimension of physical features. In order to increase the satisfaction, female students may be lead to fill out a detailed questionnaire, and what they expect from physical features can be learned. In addition to this, by judging propositions in the dimension of physical features, distance education portal can be arranged, and by providing the most recent resources in the library and access to these resources from library, level of satisfaction can be increased. Also, distance education web pages should be kept constantly up to date; they must be attractive and understandable. In addition, a secure environment in distance education portal must be provided by universities.

The differences between perceived services and desired services of students receiving education at University-1 for each dimension were found statistically significant. While the dimension where expectations of students at University-1 have not been met most is reliability, it is followed respectively by readiness, trust, empathy and physical features. In this case, by examining sub-propositions particularly starting from the dimension of reliability and by making necessary improvements, expectations of students can be met. Application-oriented studies should be focused on. A competitive environment with degrees, encouragement and reward should be provided to the students. The opportunity to interact with 
each other and with the faculty members should be provided to the students. Also, elective courses should be included in the programs.

The differences between perceived services and desired services of students receiving education at University-2 for each dimension were found statistically significant. While the dimension where expectations of students at University-2 have not been met most is physical features dimension, it is followed respectively by reliability, empathy, trust, and readiness dimensions. In this case, by examining sub-propositions particularly starting from the dimension of physical features and by making necessary improvements, expectations of students can be met. Distance education portal can be arranged, the most recent resources should be available in the library and access to these resources from library should be provided. Distance education web pages should always be kept current, appealing, understandable, and secure.

While the differences between perceived services and desired services of students receiving education at University-3 for each dimension were found statistically significant, the differences in the dimensions of reliability and trust were found insignificant, that is close to zero. While the dimension where expectations of students at University-3 have not been met most is empathy, followed respectively by readiness and physical features. In this case, by examining sub-propositions particularly starting from the dimension of empathy and by making necessary improvements, expectations of students can be met. Consultants or facilitators should help the students to complete the program without any problems for the duration of education and students should be informed about the business opportunities created by the certificate/diploma that they receive at end of the program.

The differences between perceived services and desired services of students receiving education at University-4 for each dimension were found statistically significant. While the dimension where expectations of students at University-4 have not been met most is reliability, followed by readiness, trust, empathy, and physical features. In this case, by examining sub-propositions particularly starting from the dimension of reliability and by making improvements, expectations of students can be met. In courses, application-oriented studies should be focused on. A competitive environment with degrees, encouragement and reward should be provided to the students. The opportunity for students to interact with each other and with the faculty members should be provided. Also elective courses should be included in the programs.

The differences between perceived services and desired services of students receiving education at University-5 for each dimension were found statistically 
significant. While the dimension where expectations of students at University-4 have not been met most is readiness, followed respectively by empathy, reliability, physical features, and trust. In this case, by examining sub-propositions particularly starting from the dimension of readiness and by making necessary improvements, expectations of students can be met. Faculty members should provide to students every consulting service about the University as well as the program, and should be available to students. Administrative staff should deal with them in person. The library staff should have the ability to meet demands and needs of the student.

While no difference was found between the scores of the quality of service of universities in terms of physical features and empathy according to the students of e-MBA programs, statistically significant differences were found between the scores of the quality of service of trust and overall quality of service (SERVQUAL score). Features such as the Internet, web page, education portal and their security which constitute physical features are becoming features of the first priority and providing a competitive advantage for any sector through advancing technological capabilities. Since almost identical facilities are available at universities, it is an expected situation that there may be a difference between them in terms of the dimension of physical features.

Whereas expectations of students at all universities have not been met in the dimension of physical features, sufficient evidence has not been discovered to say that there is a difference between the universities in terms of quality of service. This result does not alter the fact that universities need a certain period of time since their establishment in order to make up their deficiencies and to provide a good education. Universities established at first with a large number of deficiencies reduce their deficiencies gradually within the course of time with the increase in the number of their students and experiences.

As for the score of the quality of service of the dimension of reliability; the expectations of the students of the University-3 is different than the expectations of the students of University-1, of University-2, and of University-4. The dimension of reliability is an indication of whether or not the administrative structure of the university providing the service has been created. The dimension of reliability is also about activities such as doing jobs in time and as promised, and that faculty members do their jobs properly. University-3 meets expectations of students for reliability more than students of University-1, of University-2, and of University-4. Sufficient evidence has not been discovered to make any comparison between University-3 and University-5, and between each of other universities. That is, it can be said that there is no difference in terms of reliability. 
As for the score of the quality of service of the dimension of readiness; the expectations of the students of the University-2 is different than the expectations of the students of University-1. This dimension reveals the importance of teaching staff for good quality of education to be provided by the schools. The dimension of readiness includes criteria such as efforts of faculty members to improve students' knowledge and skills, to be exemplary to the students; to deal with the students' problems, and to find answers for questions asked them at every opportunity. University-2 meets expectations of its students for readiness more than University1. Sufficient evidence has not been discovered to make any comparison between other universities for readiness.

As for the score of the quality of service of the dimension of trust; the expectations of students of University-3 are different than those of students of other universities. University-3 meets expectations of its students for trust more than other four universities. Sufficient evidence has not been discovered to make any comparison between each of other universities, meaning that there is no difference in terms of trust.

While in the dimension of empathy expectations of students of all universities are not met; sufficient evidence has not been discovered to say that there is a difference between universities in terms of the score of the quality of service. Propositions that faculty members should help for the careers of students and advise them, that consultants should help the student to complete the program without any problems, and that students should be informed about the business opportunities created by the certificate/diploma that they receive at end of the program are within the dimension of empathy.

According to these results, it is seen that the overall perceptions has remained below the overall expectations, and there has been a general dissatisfaction. In this case, it is clear that in order to increase the quality of services, and thus to increase student satisfaction, first of all the dimension of readiness should be displayed sensitivity. It should be followed respectively by dimensions of reliability, empathy, physical features and trust. In this case, by examining sub-propositions particularly starting from the dimension of readiness and by making necessary improvements, expectations of students can be met. Faculty members should provide to students every consulting service about the University and the program, and should be available to students. Administrative staff should deal with them in person. The library staff should have the ability to meet demands and needs of the student In addition, propositions for the dimension of reliability should be handled. A competitive environment with degrees, encouragement and reward should be provided to the students. The opportunity to interact with each other and with the 
faculty members should be provided to the students. Also elective courses should be included in the programs.

By examining propositions for the dimension of empathy, which is ranked as the third in the order of importance, improvements should be done in the practice. In accordance with this, faculty members should guide students for their careers. Consultants should help the student to complete the program without any problems, and students should be informed about the business opportunities created by the certificate/diploma that they receive at end of the program.

The dimension which is ranked fourth is the dimension of physical features. According to this dimension, distance education portal should be arranged, the most recent resources should be available in the library and access to these resources from library should be provided. Distance education web pages should be kept up to date; they must be remarkable and understandable. In addition to this, a secure environment in distance education portal must be provided by universities. The last dimension to meet the expectations of students is the dimension of trust. By examining sub-propositions of the dimension of trust, and by making necessary improvements, expectations of students can be met.

The demands and needs of students are critical to the design of educational systems and to improve them in the following years. Identifying the expectations of the students from higher education, measuring the quality of the service they receive through the eyes of students, will be one of the most important elements that the higher education institutions should take into account to develop their quality management system. The authorities of the universities should examine the causes and consequences of assessments of the students, and produce solutions for their negative assessments. These assessments should be repeated at regular intervals, and to what extent applied solutions are realized should be followed. The present and similar studies should be continuously and regularly conducted in all universities, and they can be used as an important tool to enhance the quality of education in universities.

\section{References}

Abdullah, F. (2006). Measuring service quality in higher education: Three instruments compared. International Journal of Research \& Method in Education, 29, 71-89.

Altınbasak, I., Akyol A., Alkibay, S., Arslan M., Burnaz, S., Cengiz, E., Erdil, S., Gegez, E., Gunay, N., Madran, C., Sekerkaya, A., Uydaci, M., Unusan, C., Yalci, A., \& Yolac, G. (2008). Kuresel pazarlama yonetimi (1. baski). Istanbul: Beta. 
Altunkaya, N. (1997). Egitim sorunumuza kuş bakisi. Ankara: Urun.

Armstrong, G. \& Kotler, P. (2000). Marketing: An introduction ( $5^{\text {th }}$ ed.). Upper Saddle River, NJ: Prentice Hall.

Cronin, J. J. \& Taylor, S. A. (1994, January). SERVPERF versus SERVQUAL: Reconciling performance-based and perceptions-minus-expectations measurement of service quality. Journal of Marketing, 58(1), 125-131.

Crosby, P. B. (1979). Quality is free: The art of making quality certain. New York: New American Library.

Cabuk, S., Inan, H., \& Mutlu, S. (2007). Gida sektorunde hizmet kalitesinin olculmesi (Adana kentsel alanda kebapci ornegi). Cukurova Universitesi Sosyal Bilimler Enstitusu Dergisi, 16(2), 85-96.

Degermen, H. A. (2006). Hizmet urunlerinde kalite, musteri tatmini ve sadakati: Hizmet kalitesi ile musteri sadakatinin saglanması ve GSM sektorunde bir uygulama. Istanbul: Türkmen.

Deming, W. E. (1998). Krizden cikis (Trans. C. Akas). Istanbul: Kalder.

Eleren, A., Bektas, C., \& Gormus, A. S. (2007). Hizmet sektorunde hizmet kalitesinin SERVQUAL yontemi ile olculmesi ve hazir yemek isletmesinde bir uygulama. Finans Politik \& Ekonomik Yorumlar Dergisi, 44, 75-88.

Etzel, M. J., Walker, B. J., \& Stanton, W. J. (1997). Marketing $\left(11^{\text {th }}\right.$ ed.). New York: McGraw-Hill.

George, D. \& P. Mallery. (2001). SPSS for Windows step by step: A simple guide and reference 10.0 update (3th press). Boston, MA: Allyn \& Bacon.

Gegez, A. E. (2010). Pazarlama arastirmalari (Gelistirilmis 3. baski). Istanbul: Beta.

Karahan, K. (2000). Hizmet pazarlaması (1. baski). Istanbul: Beta.

Kotler, P. (1994). Marketing management: Analysis, planning, implementation and control ( $8^{\text {th }}$ ed.). Englewood Cliffs, NJ: Prentice Hall.

Kotler, P. \& Armstrong, G. (2006). Principles of marketing $\left(11^{\text {th }}\right.$ ed.). Englewood Cliffs, NJ: Prentice Hall.

Kotler, P. (2003). Marketing management (11 ${ }^{\text {th }}$ ed.). Englewood Cliffs, NJ: Prentice Hall.

Nakip, M. (2006). Pazarlama arastirmalari: Teknikler ve uygulamalar (2. basım). Ankara: Seckin.

Parasuraman, A., Zeithaml, V. A., \& Berry. L. L. (1985). A conceptual model of service quality and its implications for future research. Journal of Marketing, 49, 41-50. 
Parasuraman, A., Zeithaml, V. A., \& Berry, L. L. (1988). SERVQUAL: Multiple-item scale for measuring consumer perceptions of service quality. Journal of Retailing, 64(1), 12-40.

Parasuraman, A. \& Berry, L. L. (1991). Marketing services: Competing through quality. New York: Macmillan.

Parasuraman, A., Zeithaml, V. A., \& Berry, L.L. (1994). Reassessment of expectations as a comparison standard in measuring service quality: Implications for future research. Journal of Marketing, 58, 111-24.

Sekerkaya, A. K. (1997). Bankacilik hizmetlerinde algilanan toplam kalite olcumu. Ankara: Sermaye Piyasası Kurulu (Yayin No:87).

Turk Dil Kurumu. (2005). Turkce sozluk. Ankara: Turk Dil Kurumu.

Turkiye Istatistik Kurumu (DIE-TUIK). (2009, 13 Subat). Dunya'da ve Turkiye'de hizmet sektoru verileri. Retrieved on 30 March 2009 from http://www.die. gov.tr.

Zeithaml, V. A., Berry L. L., \& Parasuraman, A. (1988). Communication and control processes in the delivery of service quality. Journal of Marketing, 52(2), 3548.

Zeithaml, V. A., Berry L. L., \& Parasuraman, A. (1996).The behavioral consequences of service quality. Journal of Marketing, 60(2), 31-46.

Zeithaml, V. A. \& Bitner, M. J. (2003). Services marketing (3rd ed.). New York: McGraw-Hill.

Zeithaml, V.A., Bitner, M. J., \& Dwayne, D. G. (2006). Services marketing: Integrating customer focus across the firm ( $4^{\text {th }}$ ed.). New York: McGraw-Hill.

Correspondence: Kader Oskaybas, Assistant Professor, Faculty of Economic and Administrative Sciences, Maltepe University, Istanbul, Turkey 